\title{
RAISING AWARENESS AND ACTION ORIENTATION OF PEOPLE'S PUBLIC SECURITY PRACTITIONER ABOUT THE WORK OF PARTY BUILDING BY ACTIVITIES IN THE HO CHI MINH COMMUNIST YOUTH UNION
}

\author{
Nguyen Quoc Duy \\ The People's University of Police
}

\begin{abstract}
Over nearly 90 years of growth and development, the Ho Chi Minh Communist Youth Union has played a very important role in building and protecting the Socialist Republic of Vietnam. In particular, the importance of the Youth Union in building the Party must be necessarily mentioned. On the fundamental of applying the methodology of Marxism - Leninism, the methods of analysis, synthesis, logic, history, the article analyzed and clarified the role of Ho Chi Minh Communist Youth Union towards the work of building the Party and initially proposed some solutions to raise the awareness and orientate action of Police students on the Party building work through their activities in the Youth Union.
\end{abstract}

Key words: People's Public Security; Youth Union; Practitioners; Ho Chi Minh; Party Building.

Received: 15/01/2020; Revised: 11/02/2020; Published: 21/02/2020

\section{NÂNG CAO NHẤN THỨC VÀ ĐINH HƯỚNG HÀNH ĐỘNG CỦA HỌC VIÊN CÁC TRƯờnG CôNG AN NHẦN DÂN VÊ CÔNG TÁC XÂY DỰG ĐẢNG QUA HOẠT ĐộNG TRONG ĐOÀN THANH NIÊN CộNG SẢN HỒ CHÍ MINH}

\author{
Nguyễn Quốc Duy \\ Trường Đại học Cảnh sát nhân dân
}

\section{TÓM TẮT}

Trải qua gần 90 năm trưởng thành và phát triển, Đoàn Thanh niên Cộng sản Hồ Chí Minh đã đóng vai trò hết sức quan trọng trong việc xây dựng và bảo vệ Tổ quốc Việt Nam xã hội chủ nghĩa. Trong đó, cần thiết phải đề cập đến tầm quan trọng của Đoàn Thanh niên với công tác xây dựng Đảng. Trên cơ sở vận dụng phương pháp luận của Chủ nghĩa Mác - Lênin, các phương pháp phân tích, tổng hợp, lôgíc, lịch sử, bài viết đã phân tích làm rõ vai trò của Đoàn Thanh niên Cộng sản Hồ Chí Minh với công tác xây dựng Đảng và bước đầu đề ra một số giải pháp nâng cao nhận thức, định hướng hành động của các học viên Công an nhân dân về công tác xây dựng Đảng qua hoạt động trong Đoàn Thanh niên của học viên Công an nhân dân.

Từ khóa: Công an nhân dân; Đoàn Thanh niên; Học viên; Hồ Chí Minh; Xây dựng Đảng.

Ngày nhận bài: 15/01/2020; Ngày hoàn thiện: 11/02/2020; Ngày đăng: 21/02/2020

Email: nguyenduyllctt48@gmail.com

DOI: https://doi.org/10.34238/tnu-jst.2020.03.2550 


\section{Introduction}

The Ho Chi Minh Communist Youth Union is an organization which connects young people, trains and fosters promising youth generations for the country. But above all, the Youth Union is the "extended arm", the reserve team, the closest mass organization of the Party, directly led by the Party. For that reason, the Youth Union plays the important role in building the Party.

Training students to become Police officers, which is also the process of cultivating party members to prolong the revolutionary tradition of the Communist Party of Vietnam, is the responsibility of all Schools in the Armed Forces. In order to do this, students' awareness on building the Party through activities of the Youth Union of all Schools in the Armed Forces has to be raised and oriented. It is included leading step by step the union members, young people firmly grasp and cultivate themselves in the right direction.

\section{Ho Chi Minh Communist Youth Union in party construction work}

Ho Chi Minh Communist Youth Union is influenced by President Ho Chi Minh. Ho Chi Minh was the first one who establishes training foundation for the first generations of our country to follow the proper revolutionary path of Marxism - Leninism. Recognizing the importance of Union work, from the Second Central Committee Conference (1931), the Party Central Committee set out the requirement for strongly developing the Union work and establishing Ho Chi Minh Communist Youth Union. Over nearly 90 years of growth and development, the Ho Chi Minh Communist Youth Union has played a very important role in building and protecting the Socialist Republic of Vietnam. In particular, the importance of the Youth Union in building the Party must be necessarily mentioned. The role of the Youth Union in building the Party is reflected in the following main contents:
Firstly, the Ho Chi Minh Communist Youth

Union plays a role in attracting, encouraging and organizing the youth to implement the resolutions of the Party Committees.

Right from the first days of finding the right way to save our country, Ho Chi Minh correctly recognized the role of young people, at the same time emphasized the necessary to realize and persuade young people into the revolutionary movement. He said, "Youth Union "is an effective arm of the Party in order to implement revolutionary guidance and policies" [1; p.439]. Truly, the Youth Union is the organization that attracts, encourages and organizes the assault youth force to carry out and contribute to the success of the Party's Resolution at all levels. Because youngters are creative, positive, proactive and enthusiastic in performing assigned tasks. The Youth Union is an extended arm of the Party and has responsibility to make young people understand clearly the basis of the Party's guidance and policies, the country's policies and laws, and approaches the youth to seriously and effectively implement those as well as has good results in employing. In fact, we can easily understand that if the activities of the branches thrive and attract numerous young people to the Youth Union in order to educate, encourage and organize young people enthusiastically implement the resolutions of the Party Committee, the tasks proposed by the Party Committee are effectively implemented. Therefore, the Youth Union always outlines flexible, creative methods to attract young people into the activities of mass organizations, this is the actualization of resolutions of the Party Committee. Through these practical activities, the youth union members are not only practiced under the leadership of the Party but also constantly fostered class stance, fostered their own opinions and scientific method of Marxism - Leninism. 
Secondly, the Youth Union plays the role of political-ideological education and create a reserve team for the Communist Party of Vietnam.

As a socio-political organization of young people in training and fostering young people to increasingly develop the right revolutionary stance, political and ideological education is an important aspect of work of Youth Union. Through various meetings, mass activities, education sessions for basic political theory (subjects of political theory and other social sciences), undertakings and lines of the Party, policies and laws are directly and indirectly propagandized by Youth Union; it helps generations of unionists and young people to properly determine the ideal of living (especially the ideal of successfully implementing the cause of national independence and socialism), find out the direction to improve themselves follow the proletariat position, respect the people; to be good models in implementing the Party and country's rules; absolutely criticize and fight against negative and passive expressions among young people, overcome limitations and persuade misleading young people to find the right way of revolution; educate and train young people in both talents and virtues to introduce to the Party and adding Party cadres; etc.

In the Will, President Ho Chi Minh affirmed, "Fostering the revolutionary generation for the next is a crucial thing" [2; tr. 612]. By promoting the political-ideological education role, enticing union members and youth to carry out the leadership of the Party and other work fields, the Youth Union really has much special importance in personnel construction. Politically, the Youth Union educates the youth about the stance of the proletariat, about the historical mission of the proletariat in building a good social regime for Vietnam and for humanity; ideologically, the Youth Union coordinated to educate and train the worldview and scientific methodology of Marxism - Leninism for union members and youth; in terms of organization, the Youth Union gradually makes its members and youth familiar with the radical revolution, organization, discipline of the working class; morally, the Youth Union educates its members, the youth about revolutionary morality, the heroic spirit, sacrifices for the lives of the generations of his predecessors, of President Ho Chi Minh, leaders of the Party, the country and revolutionary heroes of Vietnam, etc. Thereby, the Youth Union really contributed to build the Party's reserve force, train the generations of Youth Union members and youth to be ready for keeping on the Party's revolutionary career.

Thirdly, Ho Chi Minh Communist Youth Union plays a role in contributing and criticizing the Party organizations.

As an organization which collects opinions, be a voice, trains and fosters young people, Ho Chi Minh Communist Youth Union plays an important role in contributing ideas in the construction work of Party building, training, motivating and organizing youth to actively participate in building grassroots organizations. In the field of revolutionary practices, because party members cannot work alone, they must guide, attract and unite different forces in the masses to realize revolutionary goals. Among those forces, the youth force, which is dense and active, always stands by the Communist Party members. Union members are those who always support and understand party members. Thus, in the work of building the Party, union members are the pioneers in giving opinions and objectively criticizing the activities of the Party organizations and the Party members' morality, status and activities. Through that feedback, our Party can re-evaluate merits and demerits of various activities to improve the Party's leadership. In order to excellently doing these things, the 
Youth Union constantly helps each young person and union member firmly grasps his/her position, role and responsibility for the Party's construction and development work; his/her comments and criticizations have to be straight and objective to make our Party great and develop as President Ho Chi Minh once said, "The Party is each of us. The party grows up because each of us grows up" [3; p.272].

3. People's security students raise their awareness and orient their actions in participation through activities in the $\mathrm{Ho}$ Chi Minh Communist Youth Union

In recent years, the Ho Chi Minh Communist Youth Union in all People's Public Security Schools has always been interested in and deeply participated in the work of building Party and considers it is an important task to enhance capacity and leadership of the Party Committee. In order to make this possible, the Youth Union of all People's Public Security Schools always follows the resolutions, instructions and plans of the Central Executive Committee, the Central Police Party Committee and the General Department Party Committee about the work of developing party members; well carries out the political-ideological education through thoroughly grasping the Party's resolutions, policies, guidelines, policies and laws; improves the quality of the Party and Industry campaigns; well implements major political activities to help youth union members have deeper awareness of the traditions of the Party, the people and the People's Police force; promotes ethical education, clean and healthy lifestyles; expands and promotes good models in union members and youths of the People's Public Security Forces; fosters and improves the quality of grassroots organizations and political bravery of union members; does well the task of advising the Party Committee at all levels to direct the Youth Union and youth movement more and more effectively, etc. Thereby, Ho Chi Minh
Communist Youth Union in the People's Police academies and schools has played a crucial role as the "extended arm" of the Party and participates in the Party's construction work increasingly into reality. In the coming time, in order to thoroughly grasp the role of raising awareness and orienting action of Police students about Party building through activities of the Youth Union, this can be done by these basic methods:

Firstly, raising awareness of the Party Committees, officers and lecturers of the People's Public Security Institutes about the importance of the Youth Union to the Party building.

Because of the importance of the Youth Union to the work of building the Party, it is necessary to constantly raise the awareness of the Party Committees, officers and lecturers of the People's Public Security Institutes and schools about the Union work and the youth movement. In order to improve the effectiveness of the Youth Union's activities, especially in contributing to improve the efficiency of the Party building work in the People's Police schools, it is compulsory to formulate practical solutions, plans, orientations and activities. In particular, the aspects of political - ideological education for union members and youth have to be paid attention to; create favorable conditions for union members and young people to participate in all aspects of Party building work, such as contributing opinions on the elaboration of documents of the Party Congress at all levels, giving comments and criticizing activities of Party organizations and officials, party members; organizing thorough study sessions, implement the Party's instructions and resolutions; always supervising and guiding, fostering generations of union members and young people who are not only "excellent" but also "professional" to become the Party's successor; etc. 
Secondly, excellently doing the politicalideological education and raising awareness of students about the importance of participating in the Party building.

Students of the People's Police academies and schools - due to their specific work - have been assessed through politics, health, learning ability (and other criteria) to become a police officer. Therefore, it is the People's Police students who are one of the most capable, highly revolutionary spirits who want to follow the heroic revolutionary tradition of his forefathers and strive to become party members or a true communist.

However, in order to have a proper view of the Party building, students of the People's Public Security Forces need to be fostered in terms of politics - ideology and raised awareness in terms of this work. The Party Committees at all levels and the Youth Union should have the ideal educational orientation, beliefs and worldviews of union members and the youths of the academies and the People's Public Security School which closely follows the standards of party members; make union members and youths aware of the purpose of Youth Union activities and youth movements to cultivate trainees' dignity and talents, as well as satisfy the requirements of construction and protection our country, take part in the work of building the Party, becoming a true party member, etc. Only when fostering the right awareness for students of People's Public Security schools about activities in the Youth Union about Party building, their thought and actions can be met the requirements of current circumstances.

Thirdly, continuously improving the quality of Youth Union activities and youth-oriented movements towards promote the role of Party building.

In order to maximize the role of Youth Union in Party building activities, it is indispensable to constantly improve the quality of Youth Union activities and youth movement in a specific direction. The direction of the Union in implementing is attacked with campaigns, directives and resolutions of the Party, the Ministry of Public Security, the People's Police Schools, such as the Resolution of the $12^{\text {th }}$ Party Congress of the Party, directives and resolutions of the Central Police Party Committee, Academy Party Committees of People's Public Security Schools, Directive No. 05-CT/TW, dated $15 / 5 / 2016$ of the Politburo (Promote learning, practicing and following Ho Chi Minh's ideology, morality and style), Directive 07/CT-BCA, October 26th, 2016 by the Minister of Public Security (Strengthening leadership to improve the culture of behavior of the People's Public Security in the new situation), the campaign "Building the style of the courageous People's Police for serving the people". Upgrading the quality of practical activities, Union activities in the direction of clear political-ideological orientation, focusing on educational activities, worldview, scientific methodology and revolution for learning tablets. Making students understand that it is both a requirement of the Public Security Sector and a requirement of the new revolutionary generation according to the stance of Proletariat by continuously implementing discipline of students of People's Public Security schools. In particular, intensifying the role of good models in promoting the activities of the Youth Union in association with the work of building the Party, setting an example for leaders, commanders, union leaders, typical union members to motivate and replicate in the next generations.

\section{Conclusions}

The Youth Union under the direct leadership of the Communist Party of Vietnam is also an indispensable part, the extended arm of the party to create a continuation force and 
constantly broaden our party. Specifically, the Ho Chi Minh Communist Youth Union takes part in attracting, encouraging and organizing the youth to implement the resolutions of the Party Committee at all levels; Youth Union plays the important role of politicalideological education, building a reserve team for the Communist Party of Vietnam; Ho Chi Minh Communist Youth Union joins in contributing and criticizing the Party organizations at all levels. Therefore, students of the People's Police academies and universities need to be oriented to the awareness and correct actions in the work of building the Party through activities of the Youth Union by some solutions, such as upgrading knowledge of the Party committee, officers and lecturers of the People's Police schools and academies about the importance of the Youth Union with the work of building the Party; implementing well the politicalideological education and raising awareness of students about the importance of participating in the work of building the Party; continuously improving the quality of Union activities and youth movements which is oriented to promote the role of Party building work.

\section{REFERENCES}

[1]. Ho Chi Minh's Complete works (in Vietnamese), vol. 10, Ha Noi: The National Political Publishing House, 2011.

[2]. Ho Chi Minh's Complete works (in Vietnamese), vol. 15, Ha Noi: The National Political Publishing House, 2011.

[3]. Ho Chi Minh's Complete works (in Vietnamese), vol. 13, Ha Noi: The National Political Publishing House, 2011. 